Board of Governors of the Federal Reserve System

International Finance Discussion Papers

Number 844

October 2005

The Response of Global Equity Indexes to U.S. Monetary Policy Announcements

Jon Wongswan

NOTE: International Finance Discussion Papers are preliminary materials circulated to stimulate discussion and critical comment. References to International Finance Discussion Papers (other than an acknowledgment that the writer has had access to unpublished material) should be cleared with the author or authors. Recent IFDPs are available on the Web at www.federalreserve.gov/pubs/ifdp/. This paper can be downloaded without charge from Social Science Research Network electronic library at http://www.ssrn.com/. 


\title{
The Response of Global Equity Indexes to U.S. Monetary Policy Announcements
}

\author{
Jon Wongswan*
}

\begin{abstract}
This paper documents the impact of U.S. monetary policy announcement surprises on equity indexes in sixteen countries, covering both developed and emerging economies. Using high-frequency intraday data, I find a large and significant response of Asian, European, and Latin American equity indexes to U.S. monetary policy announcement surprises at short time horizons. In this paper, I use two proxies for monetary policy surprises: a surprise change to the current target federal funds rate, and a revision to the path of future monetary policy (Gürkaynak, Sack, and Swanson (2004)). Consistent with results for the U.S. equity market, this paper finds that in most cases foreign equity indexes react only to a surprise change in the current target rate. On average, a hypothetical unanticipated 25-basis-point cut in the federal funds target rate is associated with a $1 / 2$ to $2 \frac{1}{2}$ percent increase in foreign equity indexes. The variation of the response across countries appears to be more related to the degree of financial integration with the United States than it is to trade linkages with the United States or the degree of exchange rate flexibility.
\end{abstract}

Keywords: monetary policy announcements, international stock markets, high-frequency data

JEL Classification: E44, E52, G14, G15

\footnotetext{
* Economist in the Division of International Finance of the Board of Governors of the Federal Reserve System. I thank Refet Gürkaynak for providing monetary policy announcement surprises data, David Berger and Jon Faust for providing high-frequency intraday equity market indexes data, and Jacques Miniane for discussions on the construction of capital control measures. I thank Sigga Benediktsdottir, Mark Carey, Alain Chaboud, Joe Gagnon, Mico Loretan, John Rogers, Jennifer Roush, Jonathan Wright, and participants at the IF Tuesday Lunch Group for helpful comments and suggestions. Research assistance from Priscilla Harvison, Autria Mazda, and especially Joshua Hausman and Sarita Subramanian was greatly appreciated. Of course, I take responsibility for any and all errors. For questions and comments, please contact Jon Wongswan. Email: Jon.Wongswan@,frb.gov. The views in this paper are solely the responsibility of the author and should not be interpreted as reflecting the views of the Board of Governors of the Federal Reserve System or of any other person associated with the Federal Reserve System.
} 


\section{Introduction}

Extensive studies have documented a significant relationship between U.S. monetary policy and U.S. equity prices, but only a few studies have examined the relationship between U.S. monetary policy and foreign equity prices (e.g., Bailey (1990) and Conover, Jensen, and Johnson (1999)). ${ }^{1} \quad$ Bailey (1990) finds weak evidence of foreign equity market responses to Federal Open Market Committee (FOMC) announcement surprises. This finding is surprising because the U.S. economy plays such an important role in the global economy. News regarding changes in U.S. monetary policy, which affect U.S. economic activity, should significantly influence foreign economic fundamentals and thus foreign equity market returns.

The weakness of the existing evidence may owe to the use of low-frequency data and to the proxies used to capture monetary policy surprises. Previous studies that use low-frequency data to examine the response of foreign equity prices to FOMC announcement surprises may fail to detect responses that are incorporated very quickly. Recent research, focusing mainly on developed economies, has shown that the response of financial markets to news, mostly macroeconomic announcements, occurs very rapidly (e.g., Ederington and Lee (1993), Fleming and Remolona (1999), and Andersen, Bollerslev, Dieblod, and Vega (2003)). ${ }^{2}$

Existing studies have frequently used survey-based measures, often obtained from Money Market Services, of expectations of the future federal funds target rate. Federal funds futures, however, may provide a better measure of market expectations. Indeed, Krueger and Kuttner

\footnotetext{
${ }^{1}$ Studies focusing on the impact of U.S. monetary policy on U.S. equity markets include Jensen and Johnson (1995), Jensen, Mercer, and Johnson (1996), Thorbecke (1997), Patelis (1997), Ehrmann and Fratzcher (2004), Rigobon and Sack (2004), Gürkaynak, Sack, and Swanson (2004), and Bernanke and Kuttner (2005). Studies focusing on the impact of U.S. monetary policy on foreign exchange rates and foreign interest rates include Husted and Kitchen (1985), Roley (1987), Tandon and Urich (1987), Arora and Cerisola (2001), Durham (2001), Ehrmann and Fratzsher (2002), Andersen, Bollerslev, Diebold, and Vega (2003, 2004), Miniane and Rogers (2004) and Robitaille and Roush (2004).

${ }^{2}$ Using high-frequency intraday data, Robitaille and Roush (2004) provide evidence for equity and bond markets in Brazil, and Wongswan (2005) provides evidence for equity markets in Korea and Thailand.
} 
(1996) show that fed funds futures yield efficient forecasts of the future fed funds rate. In addition, most previous studies have used only a single proxy for monetary policy surprises. Gürkaynak, Sack, and Swanson (2004) provide evidence that monetary policy surprises contain more than just a surprise in the announced target rate. They show that two factors are needed to capture monetary policy surprises, one for the current target rate and another for the path of future monetary policy.

This paper is the first to study the response of global equity indexes to FOMC announcement surprises using high-frequency intraday data and two proxies for U.S. monetary policy surprises. The target surprise is defined as the difference between the announced target fed funds rate and expectations derived from fed funds futures contracts. The path surprise is defined as the component of the change in one-year-ahead eurodollar interest rate futures that is uncorrelated with the target surprise. The path surprise is intended to proxy for news that market participants have learned from the FOMC's statement about the expected future path of monetary policy over and above what they have learned about the level of the target rate.

In contrast with previous studies that focus only on a single country or a few countries, I study the reaction to FOMC announcement surprises of equity markets in sixteen countries, covering both developed and emerging economies, making the empirical results more general. The sample consists of 53 FOMC announcements between September 1998 and November 2004. I focus on equity market responses because equities are the only asset class that is highly liquid across both developed and emerging economies. I examine the reaction of Latin American equity indexes in a one-hour window around the FOMC announcement. Because Asian and European markets are closed at the time of FOMC announcements (roughly 14:15 Eastern Time), I examine the overnight return reactions of Asian and European equity markets. I control for other 
important news unrelated to FOMC announcements that may occur during an overnight return window by using the net of FOMC effect return on the S\&P 500 index futures. The net of FOMC effect return is computed as the (logarithmic) change in S\&P 500 index futures between the equity market close of each country prior to the FOMC announcement and the following morning's open, excluding the component of the change that occurs in a one-hour window around the FOMC announcement.

I find that foreign equity markets do respond to FOMC announcements, and that they respond mainly to the target surprise. Furthermore, equity markets in both developed and emerging economies incorporate news about U.S. monetary policy surprises very quickly. The rapid incorporation of news effects is consistent with empirical evidence documented in various developed-economy financial markets, and it helps explain why previous studies based on lowfrequency data fail to find significant effects. I find that the size of the equity market response varies greatly across countries, ranging from the smallest response in Malaysia and the largest responses in Hong Kong and Korea (even larger than that in the United States). For example, a hypothetical unanticipated 25-basis-point cut in the fed funds target rate is associated with about $1 / 2$ percent increase in the Malaysian equity index, $13 / 4$ percent increase in the U.S. equity index, and $2 \frac{1}{2}$ percent increases in Hong Kong and Korean equity indexes. ${ }^{3}$ The paper also finds that the cross-sectional variation of the response is more related to proxies for financial integration with the United States than it is to proxies for real economic integration or exchange rate flexibility.

The remainder of the paper is organized as follows. Section 2 describes the data sources. Empirical models and results are discussed in Section 3. Section 4 examines factors that affect

\footnotetext{
${ }^{3}$ The estimated response for the United States is higher than that found in Gürkaynak, Sack, and Swanson (2004) and Bernanke and Kuttner (2005). This mainly reflects the difference in sample period.
} 
cross-country variation in the response to FOMC announcement surprises. Section 5 presents a conclusion and a discussion of the implications of my finding.

\section{Data Description}

The sample period includes all FOMC announcements from September 29, 1998 through November 11, 2004, excluding the September 17, 2001 FOMC announcement. The latter is an extreme example of a joint response by the Federal Reserve, several other central banks, and financial markets to the September 11, 2001 terrorist attacks. The sample covers 53 FOMC announcements (50 scheduled meeting decisions and 3 intermeeting decisions).

\subsection{Measure of Monetary Policy Surprises}

Gürkaynak, Sack, and Swanson (2004) provide evidence that monetary policy surprises contain more than just a surprise to the announced target rate. They show that two factors are needed to capture monetary policy surprises. The target surprise is defined as the difference between the announced target fed funds rate and expectations derived from the current-month federal funds futures contract (Kuttner (2001)), and it is computed as the change in the currentmonth federal funds futures contract rate in a thirty-minute window around the FOMC announcement (ten minutes before and twenty minutes after), adjusting for the day of the meeting within a calendar month specified in the current-month contract (Faust, Swanson, and Wright (2002) and Gürkaynak, Sack, and Swanson (2004)). ${ }^{4}$

\footnotetext{
${ }^{4}$ Fed funds futures contracts have a payout that is based on the average effective fed funds rate that prevails over the calendar month specified in the contract. Therefore, we need to adjust for the day of the month when we derive expectations of the fed funds rate. For FOMC meetings that occur in the last seven days of the month, the target surprise is computed as the unadjusted change in the next-month fed funds futures contract (Gürkaynak, Sack, and Swanson (2004)). Results are qualitatively similar when I compute the target surprise using a one-hour window around the announcement (fifteen minutes before and forty-five minutes after).
} 
The path surprise is defined as the component of the change in one-year-ahead eurodollar interest rate futures in a thirty-minute window around the announcement that is uncorrelated with the target surprise. To derive the path surprise, I run a regression of the change in one-yearahead eurodollar interest rate futures on a constant and the target surprise. The innovation from the regression is the path surprise. Coefficient estimates for this regression are shown in the note of Table 1. The path surprise reflects news that market participants have learned from the FOMC's statement about the expected future path of policy over and above what they have learned about the level of the target rate.

Table 1 shows basic statistics for the target and path surprises and the policy action. The standard deviation of the policy action is higher than those of target and path surprises, reflecting the fact that each policy step change occurs in increments of 25 basis points. The mean of the path surprise equals zero by construction. Figure 1 plots the target and path surprises together with the policy action. The two largest target surprises were intermeeting moves in early 2001 that caught market participants by surprise, as indicated by the fact that the target surprises are almost identical to actual policy actions. The largest path surprise occurred at the January 28 , 2004 FOMC announcement. As market participants expected, the FOMC did not change the target fed funds rate (target surprise was zero). The FOMC, however, dropped the previously used "considerable period" phrase from the accompanying statement, and this led market participants to revise up the path of future policy rates. This example illustrates the importance of the path surprise in capturing the overall range of monetary policy surprises. It is interesting to note that in recent periods the average target surprise has become smaller. The corresponding increase in the relative importance of the path surprise is consistent with reports that market 
participants have paid close attention to the FOMC's accompanying statements in gauging the path of future monetary policy.

\subsection{Equity Market Data}

Intraday five-minute equity market indexes data for sixteen countries are from Bloomberg. I use equity market indexes that market participants follow closely and that capture the aggregate equity market performance of each country. The sixteen equity market indexes used are the CAC 40 Index (France), the CDAX Performance Index (Germany), the Milan MIB Telematico Index (Italy), the FTSE 100 Index (the United Kingdom), the Hang Seng Index (Hong Kong), the Jakarta Composite Index (Indonesia), the Tokyo Stock Price Index (TOPIX, Japan), the Korea Composite Index (Korea), the Kuala Lumpur Stock Exchange Composite Index (Malaysia), the Straits Times Index (Singapore), the Taiwan Stock Exchange Weighed Price Index (Taiwan), the Stock Exchange of Thailand Index (Thailand), the Merval index (Argentina), the Bovespa Index (Brazil), the Bolsa Index (Mexico), and the S\&P 500 index futures (the United States). ${ }^{5}$ The trading hours of each equity market are shown in Figure 2 . The top line shows times in Eastern Daylight Saving Time (EDT), and the times below are local times (during daylight saving for Europe). The gaps in the middle of the day for equity markets in Indonesia, Japan, Malaysia, and Thailand represent market closures for lunch-time breaks. The S\&P 500 index futures is traded almost around the clock, in either regular trading session (light-blue) or electronic trading session (dark-blue). ${ }^{6}$ All scheduled FOMC announcements

\footnotetext{
${ }^{5}$ Results on the reaction of U.S. equity market to FOMC announcements are qualitatively similar when I use the S\&P 500 index instead of the S\&P 500 index futures.

${ }^{6}$ The S\&P 500 index futures' trading session closes down three times per day: between 9:15 and 9:30, between 16:15 and 16:30, and between 17:30 and 18:00 (Globex maintenance time). All times are in Eastern Time.
} 
during the sample period occurred around 14:15 Eastern Time, shown by a vertical dashed line in Figure 2.

Because Asian and European markets are closed at the time of scheduled FOMC announcements, the impact of FOMC announcements on these markets occurs overnight. To mitigate the stale quote problem for component securities in an index when calculating the opening price index (Stoll and Whaley (1990)), the overnight return is computed from the previous closing price and the price thirty minutes after the official opening time. Although this window is wide in calendar time, it covers only thirty minutes of open market time. Still, because of this wide calendar time window, there is some likelihood that other important news unrelated to FOMC announcements may affect Asian and European overnight equity returns. For example, many U.S. earnings announcements or earnings warnings are released either before the U.S. equity market opens or after the U.S. equity market closes. To minimize this problem, I use the overnight net of FOMC effect return in the S\&P 500 index futures to control for the effects of non-FOMC news. For each country, the net of FOMC effect return is computed as the (logarithmic) change in S\&P 500 index futures between the equity market close of each country prior to the FOMC announcement and the following morning after the FOMC announcements, excluding the component of the change that occurs in a one-hour window around the FOMC announcement. The net of FOMC effect return varies with the opening and closing times of each country's equity market. For example, the net of FOMC effect return for Thailand is the change in S\&P 500 index futures between 5:30 and 23:00 Eastern Time, excluding the component of the change that occurs during a one-hour window around the FOMC announcement. ${ }^{7,} 8$

\footnotetext{
${ }^{7}$ To examine the general comovement between Asian and European overnight returns and the overnight return in the S\&P 500 index futures over my sample period, I estimate a separate regression for each country of overnight return (Asian or European indexes) on a constant and an overnight return in the S\&P 500 index futures (computed the return over the same window as that for the dependent variable) over the full sample, excluding FOMC
} 
An alternative way to alleviate the impact of other non-FOMC news on Asian and European equity indexes is to use of high-frequency intraday foreign stock indexes trading in New York as Exchange Traded Funds (EFTs). However, these EFTs are not actively traded within a day and do not track the underlying national stock indexes well (Engle and Sarkar (2002)), making them unsuitable for a very short-run analysis. ${ }^{9}$

Weekly data for all sixteen equity markets are used to estimate the general comovement with the U.S. equity market. The sample is from January 1990 through November 2004.

\subsection{Proxies for Real and Financial Integration and Exchange Rate Flexibility}

I use the ratio of each country's international trade (exports plus imports) with the United States to its GDP and the ratio of each country's exports to the United States to its GDP to proxy for real economic integration. The annual trade data are from the IMF's Direction of Trade Statistics, and the annual GDP data are from the World Bank's World Development Indicator database.

I use three proxies to measure the degree of financial integration. First, I use the ratio of foreign equity holdings to each country's equity market capitalization (foreign participation ratio). Data on the equity holdings of foreign investors are from the IMF's Portfolio Investment:

announcement days (about 1,500 observations for each country). Estimates on the overnight return in the S\&P 500 index futures are statistically significant at the 95 percent confidence level for all countries. R-squared statistics are 0.5 for France, United Kingdom, and Hong Kong, 0.4 for Germany, Italy, Japan, Singapore, 0.3 for Korea, 0.2 for Malaysia, Taiwan, and Thailand, and 0.1 for Indonesia. These results are evident that the return in the S\&P 500 index futures can capture movements in Asian and European overnight returns well.

${ }^{8}$ To test the null hypothesis that the net of FOMC effect return is unrelated to FOMC announcement surprises, I regress the net of FOMC effect return for each country on both the target and path surprises. I cannot reject the null hypothesis that the coefficients on the two monetary policy surprises are equal to zero at the 95 percent confidence level, for all countries, indicating that net of FOMC effect return for each country is unrelated to FOMC announcement surprises. All empirical results are qualitatively similar when I exclude only a thirty-minute return around the FOMC announcement from the S\&P 500 index futures return to compute the net of FOMC effect return.

${ }^{9}$ Using high-frequency data on 12 foreign EFTs, Bauer and Vega (2005) find significant evidence of the role of private information about U.S. monetary policy in explaining the cross section of international equity returns at daily and weekly frequencies. 
Coordinated Portfolio Investment Survey. Equity market capitalizations used to normalize foreign holdings are from Standard \& Poor's Global Equity Market Factbook. Second, I use Miniane (2004)'s methodology to compute an index of capital control measure for each country. This index uses publicly available information contained in the IMF's Annual Report on Exchange Arrangements and Exchange Restrictions. The index is an average value of dummy variables in twelve different categories of capital transactions and a dummy variable for dual exchange rates ${ }^{10}$; countries with higher index value have more restrictive capital controls. Finally, I also use the coefficient from a regression of each country's (logarithmic) equity price changes on U.S. (logarithmic) equity price changes at weekly frequencies over the same sample period used in this study. This regression coefficient is intended to capture the generalized comovement of each country's equity market with the U.S. equity market.

To measure exchange rate flexibility, I use two proxies. First, I use a dummy variable derived from the IMF's Annual Report on Exchange Arrangements and Exchange Restrictions. The dummy variable equals one for a fixed or currency board regime, two for a limitedflexibility regime, three for a managed float regime, and four for a fully floating regime. Second, I use Reinhart and Rogoff (2004)'s measure of exchange rate regime. The IMF exchange rate classification, used in the first proxy, is based on official government announcements. Reinhart and Rogoff (2004) note that actual exchange rate regimes often differ from officially announced regimes. Reinhart and Rogoff (2004) attempt to overcome this problem by using market-determined parallel exchange rates to help classify each country's actual exchange rate regime.

10 The twelve categories are: Capital Market Securities, Money Market Instruments, Collective Investment Securities, Derivatives and Other Instruments, Commercial Credits, Financial Credits, Guarantees and Financial Back-up Securities, Direct Investment, Repatriation of Profits or Liquidation of Direct Investment, Real Estate, Specific Provisions to Commercial Banks and Other Credit Institutions, and Specific Provisions to Institutional Investors. 


\section{Do Foreign Equity Indexes Respond to FOMC Announcement Surprises?}

\subsection{Theory and Empirical Specification}

U.S. monetary policy can affect foreign equity prices through several channels, some of which are similar to the channels through which U.S. monetary policy affects U.S. equity prices.

First, a surprise increase in the fed funds rate can raise the discount rate that is applied to the expected future dividend stream, thereby tending to lower U.S. equity prices. To the extent that the fed funds rate path affects global interest rates, one might expect a higher fed funds rate would tend to raise the rate of discount in foreign countries and thus lower foreign equity prices.

Second, an unanticipated movement in the fed funds rate may also convey information about future economic activity in the United States, which in turn may affect firms' expected cash flows; however, the direction of this relationship may differ across episodes. In some instances, a higher fed funds rate may lead the market to downgrade its forecast of future economic activity, reflecting the contractionary effect of tighter monetary policy. In other instances, a higher fed funds rate may be taken as a sign of greater optimism about the strength of the U.S. economy. To the extent that U.S. economic activity influences global activity, these channels may be at work in foreign equity markets as well.

Third, a surprise in the fed funds rate can influence foreign exchange rates. The exchange rate can influence equity prices through either the discount rate component or the expected future cash flows component or both, making the net effect unclear. The strength of each component depends on the ability of the exchange rate to adjust flexibly to changes in global interest rates. For example, assume that uncovered interest rate parity holds and that the exchange rate adjusts fully to changes in global interest rates. In this case, an unanticipated increase in U.S. interest rates, which leads to an increase in global interest rates, will lead the 
dollar to appreciate against other foreign currencies and should boost foreign exports to the United States. This, in turn, may lead to increases in foreign equity prices. In contrast, suppose uncovered interest rate parity holds but the exchange rate does not adjust to changes in global interest rates. Then, a surprise increase in U.S. interest rates should lead to higher foreign interest rates which will lead to lower foreign equity prices. These are two extreme cases. Most countries' exchange rate adjustment lies somewhere between these two extremes.

Finally, a surprise change in U.S. interest rates may affect foreign equity prices through portfolio adjustments in multiple markets which are linked through institutions such as global mutual funds, hedge funds, and brokerage firms (e.g., Kyle and Xiong (2001) and Kodres and Pritsker (2002)).

The empirical methodology follows the standard event study literature. I examine equity returns in a narrow window around the FOMC announcement. For Latin American and U.S. equity markets, I use a one-hour window that begins fifteen minutes before and ends forty-five minutes after the FOMC announcement. For Asian and European equity markets, I use an overnight window that begins at the market's close before the FOMC announcement and ends one half-hour after the official opening time the next day. ${ }^{11}$ Specifically, I estimate the following regression separately for each country:

$$
R_{i, t}=a+b 1 * T S_{t}+b 2 * P S_{t}+b 3 * S \& P_{t}^{N e t}+e_{i, t}
$$

\footnotetext{
${ }^{11}$ Equity markets in the United States may take less than forty-five minutes to react to FOMC announcements; however, equity markets in Latin America may take more time to react. For comparison, I use the same window for all markets that can respond contemporaneously to the announcement. Results are qualitatively similar when I expand the window to two hours. Results for Asian and European markets are also qualitatively similar when I use the price index value after the market is open for a full hour to compute the overnight return. Results are available on request.
} 
where $R_{i, t}$ is the return of country $i$ stock market index on day $t, T S$ is the target surprise, $P S$ is the path surprise, $S \& P^{N e t}$ is the net of FOMC effect return on the S\&P 500 index futures, and $e$ is an error term. Since we can measure an immediate response in Western Hemisphere equity markets, I do not include the net of FOMC effect term in the regressions for these countries.

The regression for each country is estimated using ordinary least squares (OLS). The estimates are based only on those observations when announcements were made. Because the path surprise is an innovation from a regression of the one-year-ahead eurodollar interest rate futures on a constant and the target surprise, I need to account for the generated regressor problem when computing the standard errors in equation (1). To account for that, I compute coefficient estimates' standard errors from a sampling-with-replacement bootstrap with 1,000 repetitions. ${ }^{12}$

\subsection{Preliminary Analysis}

To investigate whether foreign equity indexes respond to FOMC announcements, I compare return volatility on days with and without FOMC announcements. Panel A of Figure 3 plots return volatility for equity markets in Latin America and the United States computed over an hour around the FOMC announcements. It is evident that volatilities on FOMC days are much higher than on non-FOMC days. The Chi-squared test statistics for all countries indicate a strong rejection of the null hypothesis of equal volatility on FOMC and non-FOMC days. Panel B of Figure 3 plots overnight return volatility for equity markets in Asia and Europe. It is evident that, in general, volatilities are higher on FOMC days than on non-FOMC days, and the differences are again statistically significant. In addition, volatilities for emerging-economy equity indexes are higher than those of developed-economy equity indexes, consistent with

\footnotetext{
${ }^{12}$ Alternatively, standard errors can be computed from White's robust standard errors. The empirical results are qualitatively very similar to those obtained from bootstrap standard errors.
} 
previous studies based on lower frequency data. (e.g., Bekaert and Harvey (1997)). Overall, the evidence on return volatility suggests that foreign equity markets do react to FOMC announcements. The next subsection explores the direction of the response to announcement surprises.

\subsection{Empirical Results}

Table 2 reports results from estimating equation (1). Panel A shows results for intraday responses of equity markets in Latin America and the United States. Estimates from using the

full sample are shown in the left columns. It is evident that equity indexes mostly respond to the target surprise, not to the path surprise. This finding is similar to that documented in Gürkaynak, Sack, and Swanson (2004) for the U.S. equity market. One possible explanation could be that information in the FOMC's statement regarding the future course of monetary policy may affect both the revision in the cash-flow and future discount rate components of equity prices that can have offsetting effect, thus leading to a muted observed reaction. For example, a statement that is viewed as more hawkish tends to lead to an increase in interest rates and may also lead to an upward revision in expectations for firm's cash-flow. It is also possible that the path surprise has become more important in recent years and that we have too few observations to estimate the effect precisely. It is interesting to note that the reaction in Latin American markets is very similar to that in the United States. For example, a hypothetical unanticipated 25-basis-point decrease in the federal funds rate leads to a $1 \frac{1}{2}$ percent increase in Argentine equity market index and a $13 / 4$ percent increase in $\mathrm{S} \& \mathrm{P} 500$ index within an hour around the announcement. The adjusted R-squared statistics show that the short-run movements in equity indexes are influenced by FOMC monetary policy surprises. 
Panel B of Table 2 shows estimates for Asian and European equity markets. The response is measured from overnight returns. Similar to the results for Western Hemisphere, equity markets in Asia and Europe mostly react to the target surprise. Estimates using the full sample show that equity markets in Korea and Hong Kong respond the most to FOMC surprises; these markets respond even more than that in the United States. ${ }^{13}$ The Malaysian equity index responds the least to FOMC announcements, partly may reflect the capital controls imposed in 1998. Also, Japanese equity index does not significantly respond to U.S. monetary policy surprises. This finding may reflect the different economic growth path of Japan during the sample period and the relative isolation of Japanese financial markets. Estimates of the average comovement between each country's overnight return and the net of FOMC effect return on the S\&P 500 index futures are shown in the fourth column for the full sample. It is evident that the net of FOMC effect return, which is designed to proxy important news that are unrelated to FOMC surprises, is highly correlated with overnight returns. The significance of these estimates underscores the importance of including a control for non-FOMC news.

As pointed out by Bernanke and Kuttner (2005), some observations of the FOMC announcement may have unusually large influences on the estimated response. Thus, I reestimate equation (1) using only scheduled announcements. I excluded all three intermeeting moves, which were also identified in Bernanke and Kuttner (2005) as having a large influence on the estimates. The parameter estimates are shown in columns six through eight. The estimated responses are still significantly negative for most countries, but are smaller in magnitude for

\footnotetext{
${ }^{13}$ Using daily data, Bailey (1990) also finds that the Hong Kong equity index responded more to FOMC announcements than the S\&P 500 index. In contrast, he does not find that Korean equity prices reacted statistically significant to FOMC announcements. This may due to the use of low frequency data and/or the capital controls in Korea. According to Miniane (2004)'s capital control measure, during my sample period Korea still has severe capital controls. Therefore, it is likely that the lack of evidence in the response for Korea may due to the use of low frequency data.
} 
countries in Asia and become insignificant for a few countries. Excluding the three intermeeting moves from the sample also decreases the adjusted R-squared substantially. I test for the statistical significance of the difference in the response to scheduled and unscheduled announcements, by interacting a dummy variable for intermeeting moves with the target surprise. I cannot reject the null hypothesis at the 95 percent confidence level that the coefficient on this interaction term equals zero for all countries; thus one cannot reject the null of no statistical difference in the equity market response to scheduled versus unscheduled announcements. ${ }^{14}$

To test whether the reaction to FOMC announcement surprises is fully incorporated in overnight returns, I also estimate equation (1) for returns computed over the first, second, third, and fourth fifteen-minute intervals following the window used for each country. For example, the first fifteen-minute interval return following the event window for Thailand is computed from thirty minutes to forty-five minutes after the Thai stock market opens. This return interval, by construction, does not contain the FOMC announcement. Therefore, if financial markets are efficient in incorporating new information, FOMC announcement surprises should not affect these fifteen-minute returns. Consistent with this hypothesis, all estimates for all countries and all fifteen-minute intervals are insignificant at the 95 percent confidence level. Results are not shown but are available on request.

\section{Explaining the Cross-Country Variations in the Response}

Results in the previous section naturally prompt the question why does the response of equity prices to FOMC announcement surprises differ across countries? Before exploring the

\footnotetext{
${ }^{14}$ I also test for the asymmetry in the response to the direction of the surprise and the direction of policy action. There is only weak evidence for these two types of asymmetry, similar to results documented in the U.S. equity market (Bernanke and Kuttner (2005)).
} 
cross-country response differences, I test whether the country responses are statistically different from one another. Following Bailey (1990), I test for the difference in the response for one pair of countries at a time. I combine observations from two countries and estimate the following equation:

$$
R_{i, t}=\mathrm{a}+\mathrm{b} 1 * T S_{t}+\mathrm{b} 3 * S \& P_{t}^{N e t}+\mathrm{c} 1 * D_{j, t} * T S_{t}+e_{i, t}
$$

where country $i$ is the base country, country $j$ is the comparison country, and $D_{j}$ equals one for observations of country $j$ and zero otherwise. I drop the path surprise term because it is not significant in most cases, as shown in Table 2. Table 3 reports the t-statistics on the estimates of the dummy interaction with the target surprise (c1). In general, within a region, equity indexes in Western Hemisphere and in Europe respond to FOMC surprises about similarly in magnitude. Equity indexes in Asia respond greatly different across countries. There are greater variations in the response across regions than within regions. Equity indexes in Hong Kong and Korea respond the most to FOMC announcements, and these two estimates are statistically larger than those for other countries, including the United States. In comparison with the response in the United States, equity markets in Europe respond less, whereas equity markets in Latin America respond similarly. Overall, the size of the response varies greatly across countries.

There are many factors that can influence the size of each country's response to FOMC announcement surprises. First, the degree of real economic integration with the United States may determine the importance of the U.S. economy to its domestic economy and thus to domestic equity prices. Second, a country that is more integrated into international financial markets should respond more to changes in foreign asset prices. To the extent that U.S. monetary policy influences global interest rates, we would expect a country that is more 
integrated to respond more. Lastly, the ability of the exchange rate to adjust flexibly to external shocks may influence the size of the equity response. A country that has only limited exchange rate flexibility will have to adjust its domestic interest rate more than a country with more exchange rate flexibility (Frankel, Schmukler, and Serven (2004) and Shambaugh (2004)). ${ }^{15}$ To the extent that movements in equity market indexes are driven mainly by the discount rate component (see Campbell (1990) for evidence in the United States and Ammer and Mei (1998) for evidence in international markets), we would expect countries with less flexible exchange rates to respond more to U.S. monetary policy surprises.

Table 4 shows the means of proxies for real and financial economic integration and exchange rate flexibility. Columns three and four show two proxies for real economic integration. These are trade with the United States as a percentage of the country's GDP and exports to the United States as a percentage of the country's GDP. ${ }^{16}$ Financial integration proxies are shown in columns five through seven. They are foreign participation in the domestic equity market (percentage of total foreign equity holdings to total equity market capitalization) ${ }^{17}$, capital control measures derived from the IMF's Annual Report on Exchange Arrangements and Exchange Restrictions (an extension of Miniane (2004)'s methodology to my sample period), and estimates of beta from a regression of the foreign equity return (in local currency) on the S\&P 500 index return. These betas are estimated from weekly data during my sample period. ${ }^{18}$ Proxies for the flexibility of exchange rate regime are dummy variables derived from the IMF's

\footnotetext{
${ }^{15}$ For example, under the Hong Kong's currency board exchange rate arrangement, the Hong Kong Monetary Authority adjusts its domestic target interest rate one-for-one with the U.S. fed funds rate.

${ }^{16}$ Results are qualitatively similar when I compute the relative size of exports and trade with the U.S. as a percentage of country's total trade.

${ }^{17}$ Results are qualitatively similar when I use U.S. investor participation in the domestic equity market (percentage of U.S. holdings in the domestic markets).

${ }^{18}$ Results are qualitatively similar when I estimate the beta with weekly or monthly data from 1990.
} 
Annual Report on Exchange Arrangements and Exchange Restriction and Reinhart and Rogoff (2004). All proxies are annual averages from 1998 through 2004, except foreign participation ratios (annual averages from 2001 through 2004) and Reinhart and Rogoff's exchange rate classification measures (annual averages from 1998 through 2001). Because several variables for Taiwan are not available, I exclude Taiwan in the cross-sectional regression analysis. The correlations among these proxies are shown in Table 5. It is evident that the two proxies for real integration and the two proxies for the exchange rate regime are highly correlated with each other, while the three proxies for financial integration are somewhat less, but still moderately correlated with each other. Comparing pairwise correlations of the size of the response to each proxy, it is evident that countries with more real and financial links to the United States respond more to FOMC announcements (more negatively correlated). Also, as expected if the discount rate component is important, countries with less flexible exchange rate regimes respond more to FOMC announcements (more positively correlated).

To conserve space, I show the cross-sectional regression results for selected variables in Table 6. I regress the estimates of the response to the target surprise (b1 from equation (1)) on proxies for real and financial integration and for exchange rate flexibility. It is evident that the cross-sectional variation in the response is more correlated with the proxy for financial integration than with the proxies for real economic integration or exchange rate flexibility. However, because the adjusted R-squared statistics range from 0.05 to 0.07 , the explanatory power of these proxies to explain the cross-sectional response variation is very low, suggesting that factors other than proxies examined in this paper must explain the difference in responses. 


\section{Conclusion}

Using high-frequency intraday data, I document economically and statistically significant evidence of an impact of FOMC announcement surprises on global equity indexes. This is direct evidence that U.S. monetary policy affects foreign economies through equity markets. In addition, it is evident that news about U.S. monetary policy is important to global equity markets. The fact that global equity markets incorporate news rapidly likely explains why previous studies based on lower frequency data have generally been unable to document such strong linkages.

In this paper, I use two proxies for monetary policy surprises: a surprise change to the current target federal funds rate, and a revision to the path of future monetary policy (Gürkaynak, Sack, and Swanson (2004)). Consistent with results for the U.S. equity market, this paper finds that in most cases foreign equity indexes react significantly only to surprises in the current target rate. The size of the response varies greatly across countries, and it is more related to proxies for financial integration than it is to proxies for real economic integration or exchange rate flexibility. 


\section{References}

Ammer, John and Jianping Mei, 1996, Measuring International Economic Linkages with Stock Market Data, Journal of Finance 51, 1743-1763.

Andersen, Torben, Tim Bollerslev, Francis X. Diebold, and Clara Vega, 2003, Micro Effects of Macro Announcements: Real-Time Price Discovery in Foreign Exchange, American Economics Review 93, 38-62.

Andersen, Torben, Tim Bollerslev, Francis X. Diebold, and Clara Vega, 2004, Real-Time Price Discovery in Stock, Bond and Foreign Exchange Markets, Working Paper Duke University.

Arora, Vivek and Martin Cerisola, 2001, How Does U.S. Monetary Policy Influence Sovereign Spreads in Emerging Markets?, IMF Staff Paper 48, 474-498.

Bailey, Warren, 1990, U.S. Money Supply Announcements and Pacific Rim Stock Markets: Evidence and Implications, Journal of International Money and Finance 9, 344-356.

Bauer, Gregory H. and Clara Vega, 2005, The Monetary Origins of Asymmetric Information in International Equity Markets, Working Paper University of Rochester's the William E. Simon School of Business.

Bekaert, Geert and Campbell R. Harvey, 1997, Emerging Equity Market Volatility, Journal of Financial Economics 43, 29-77.

Bernanke, Ben S. and Kenneth Kuttner, 2005, What Explains the Stock Market's Reaction to Federal Reserve Policy?, Journal of Finance 60, 1221-1257.

Campbell, John Y., 1991, A Variance Decomposition for Stock Returns, Economic Journal 101, 157-179.

Durham, J. Benson, 2001, The Effect of Monetary Policy on Monthly and Quarterly Stock Market Returns: Cross-Country Evidence and Sensitivity Analyses, Board of Governors of the Federal Reserve System Finance and Economics Discussion Paper No. 2001-42.

Ederington, Louis H. and Jae Ha Lee, 1993, How Markets Process Information: News Release and Volatility, Journal of Finance 48, 1161-1191.

Ehrmann, Michael and Marcel Fratzscher, 2002, Interdependence between the Euro Area and the US: What Role for EMU?, European Central Bank Working Paper No. 200.

Ehrmann, Michael and Marcel Fratzscher, 2004, Taking Stock: Monetary Policy Transmission to Equity Markets, Journal of Money, Credit, and Banking 36, 719-737. 
Engle, Robert F. and Debojyoti Sarkar, 2002, Pricing Exchange Traded Funds, New York University's Stern School of Business Working Paper.

Fleming, Michael J. and Eli M. Remolona, 1999, Price Formation and Liquidity in the U.S. Treasury Market: The Response to Public Information, Journal of Finance 52, 11111130.

Gürkaynak, Refet, Brian Sack, and Eric Swanson, 2004, Do Actions Speak Louder than Words? The Response of Asset Prices to Monetary Policy Actions and Statements, Board of Governors of the Federal Reserve System Finance and Economics Discussion Paper No. 2004-66.

Husted, Steven and John Kitchen, 1985, Some Evidence on the International Transmission of U.S. Money Supply Announcement Effects, Journal of Money, Credit, and Banking 17, 456-466.

International Monetary Fund, 1998-2004, Annual Report on Exchange Arrangements and Exchange Restrictions (Washington).

International Monetary Fund, 2001-2003, Portfolio Investment: Coordinated Portfolio Investment Survey (CPIS)

Jensen, Gerald R. and Robert R. Johnson, 1995, Discount Rate Changes and Security Returns in the U.S., 1962-1991, Journal of Banking and Finance 19, 79-95.

Jensen, Gerald R., Jeffrey M. Mercer, and Robert R. Johnson, 1996, Business Conditions, Monetary Policy, and expected Security Returns, Journal of Financial Economics 40, 213-237.

Kodres, Laura E. and Matthew Pritsker, 2002, A Rational Expectation Model of Financial Contagion, Journal of Finance 57, 769-799.

Kyle, Albert S. and Wei Xiong, 2001, Contagion as a Wealth Effect, Journal of Finance 56, 1401-1440.

Miniane, Jacques, 2004, A New Set of Measures on Capital Account Restrictions, IMF Staff Papers 51, 276-308.

Miniane, Jacques and John H. Rogers, 2003, Capital Controls and the International Transmission of U.S. Money Shocks, Board of Governors of the Federal Reserve System, International Finance Discussion Paper No. 778.

Patelis, Alex D., 1997, Stock Return Predictability and The Role of Monetary Policy, Journal of Finance 52, 1951-1972. 
Reinhart, Carmen M. and Kenneth S. Rogoff, 2004, The Modern History of Exchange Rate Arrangements: A Reinterpretation, Quarterly Journal of Economics 119, 1-48.

Rigobon, Roberto and Brian Sack, 2004, The Impact of Monetary Policy on Asset Prices, Journal of Monetary Economics 51, 1553-1575.

Robitaille, Patrice and Jennifer Roush, 2004, Responses of Emerging Market Economy Asset Prices to U.S. Events: The Case of Brazil, Mimeo, Board of Governors of the Federal Reserve System.

Roley, V. Vance, 1987, U.S. Money Announcements and Covered Interest Parity: The Case of Japan, Journal of International Money and Finance 6, 57-70.

Shambaugh, Jay C., 2004, The Effect of Fixed Exchange Rates on Monetary Policy, Quarterly Journal of Economics 119, 301-352.

Standard \& Poor's, 2001-2003, Global Stock Markets Factbook (New York).

Tandon, Kishore and Thomas Urich, 1987, International Market Response to Announcements of U.S. Macroeconomic Data, Journal of International Money and Finance 6, 71-83.

Thorbecke, Willem, 1997, On Stock Market Returns and Monetary Policy, Journal of Finance $52,635-654$.

Wongswan, Jon, 2005, Transmission of Information across International Equity Markets, Review of Financial Studies, forthcoming. 


\section{Table 1: Basic statistics}

The table shows basic statistics for policy action, target surprise, and path surprise. The sample period includes all FOMC announcements from September 29, 1998 through November 11, 2004, excluding the September 17, 2001 FOMC announcement. Path surprises are innovations from the following regression:

Changes in one-year ahead eurodollar interest rate futures $=-0.01+0.51^{\star}$ Target Surprise, $\mathrm{R}$-sq $=0.28$.

\begin{tabular}{lrrr}
\hline & Policy action & Target surprise & Path surprise \\
\hline Mean (basis points) & -5.66 & -2.08 & 0.00 \\
Standard deviation (basis points) & 24.34 & 10.06 & 8.25 \\
Number of observations & 53 & 53 & 53 \\
Correlation with policy action & & 0.44 & 0.19 \\
\hline
\end{tabular}


Table 2: Regressions of equity index returns on target and path surprises

This table shows estimates from the regression of equity index returns on target and path surprises (equation (1)):

$$
R_{i, t}=a+b 1 * T S_{t}+b 2 * P S_{t}+b 3 * S \& P_{t}{ }^{N e t}+e_{i, t}
$$

where $R$ is the country index return, IS is the target surprise, $r S$ is the path surprise, and $S \& P^{\cdots}$ is the net of FOMC effect return on the S\&P 500 index futures. The sample period includes all FOMC announcements from September 29, 1998 through November 11, 2004, excluding the September 17, 2001 FOMC announcement. Standard errors are in parentheses and are computed from a sampling-with-replacement bootstrap with 1,000 repetitions. Coefficients significant at the $5 \%$ level are in bold, and coefficients significant at the $10 \%$ level are Inderlined

\begin{tabular}{|c|c|c|c|c|c|c|c|c|}
\hline & \multicolumn{4}{|c|}{ Full sample } & \multicolumn{4}{|c|}{ Excluding intermeeting moves } \\
\hline & b1 & b2 & b3 & Adj. R-sq & b1 & b2 & b3 & Adj. R-sq \\
\hline \multicolumn{9}{|c|}{ Panel A: Contemporaneus returns } \\
\hline Argentina & $\begin{array}{c}-6.00 \\
(2.86)\end{array}$ & $\frac{-3.32}{(1.77)}$ & & 0.36 & $\begin{array}{l}-0.60 \\
(1.36)\end{array}$ & $\frac{-1.89}{(0.98)}$ & & 0.06 \\
\hline Brazil & $\begin{array}{c}-7.15 \\
(1.48)\end{array}$ & $\begin{array}{l}-1.23 \\
(1.68)\end{array}$ & & 0.42 & $\begin{array}{l}-2.96 \\
(1.41)\end{array}$ & $\begin{array}{c}-0.69 \\
(1.83)\end{array}$ & & 0.04 \\
\hline Mexico & $\begin{array}{c}-6.13 \\
(2.11)\end{array}$ & $\begin{array}{l}-2.04 \\
(1.56)\end{array}$ & & 0.38 & $\begin{array}{c}-\mathbf{2 . 8 2} \\
(1.42)\end{array}$ & $\frac{-1.98}{(1.15)}$ & & 0.08 \\
\hline U.S. & $\begin{array}{l}-7.15 \\
(1.43)\end{array}$ & $\begin{array}{l}-1.89 \\
(1.51)\end{array}$ & & 0.49 & $\begin{array}{c}-4.26 \\
(1.94)\end{array}$ & $\begin{array}{l}-1.75 \\
(1.51)\end{array}$ & & 0.10 \\
\hline \multicolumn{9}{|c|}{ Panel B: Overnight returns } \\
\hline France & $\begin{array}{l}-5.10 \\
(0.99)\end{array}$ & $\begin{array}{c}0.31 \\
(1.42)\end{array}$ & $\begin{array}{c}\mathbf{0 . 6 0} \\
(0.16)\end{array}$ & 0.35 & $\begin{array}{c}-5.12 \\
(2.07)\end{array}$ & $\begin{array}{c}0.16 \\
(1.59)\end{array}$ & $\begin{array}{c}\mathbf{0 . 6 1} \\
(0.19)\end{array}$ & 0.25 \\
\hline Germany & $\begin{array}{l}-3.94 \\
(1.40)\end{array}$ & $\begin{array}{l}-1.16 \\
(1.33)\end{array}$ & $\begin{array}{c}\mathbf{0 . 5 6} \\
(0.15)\end{array}$ & 0.35 & $\begin{array}{l}-3.67 \\
(1.69)\end{array}$ & $\begin{array}{c}-0.12 \\
(1.22)\end{array}$ & $\begin{array}{c}\mathbf{0 . 5 7} \\
(0.16)\end{array}$ & 0.29 \\
\hline Italy & $\begin{array}{l}-3.93 \\
(0.94)\end{array}$ & $\begin{array}{l}-0.16 \\
(1.11)\end{array}$ & $\begin{array}{c}\mathbf{0 . 4 4} \\
(0.11)\end{array}$ & 0.40 & $\begin{array}{c}-2.65 \\
(1.89)\end{array}$ & $\begin{array}{c}0.27 \\
(1.12)\end{array}$ & $\begin{array}{c}\mathbf{0 . 3 8} \\
(0.11)\end{array}$ & 0.22 \\
\hline U.K. & $\begin{array}{c}-4.44 \\
(0.95)\end{array}$ & $\begin{array}{l}-0.08 \\
(1.15)\end{array}$ & $\begin{array}{c}\mathbf{0 . 4 4} \\
(0.11)\end{array}$ & 0.52 & $\begin{array}{l}-1.79 \\
(1.83)\end{array}$ & $\begin{array}{c}0.47 \\
(1.04)\end{array}$ & $\begin{array}{c}\mathbf{0 . 4 6} \\
(0.11)\end{array}$ & 0.35 \\
\hline Hong Kong & $\begin{array}{c}-9.53 \\
(2.14)\end{array}$ & $\frac{-3.48}{(1.94)}$ & $\begin{array}{c}\mathbf{0 . 6 2} \\
(0.14)\end{array}$ & 0.63 & $\begin{array}{c}-6.57 \\
(2.26)\end{array}$ & $\begin{array}{l}-2.35 \\
(1.83)\end{array}$ & $\begin{array}{c}\mathbf{0 . 5 4} \\
(0.13)\end{array}$ & 0.35 \\
\hline Indonesia & $\begin{array}{l}\mathbf{- 3 . 1 8} \\
(1.48)\end{array}$ & $\begin{array}{l}-2.62 \\
(2.06)\end{array}$ & $\begin{array}{c}0.27 \\
(0.19)\end{array}$ & 0.11 & $\frac{-4.48}{(2.32)}$ & $\begin{array}{l}-1.02 \\
(1.79)\end{array}$ & $\begin{array}{c}0.15 \\
(0.19)\end{array}$ & 0.02 \\
\hline Japan & $\begin{array}{l}-3.28 \\
(2.55)\end{array}$ & $\begin{array}{l}-1.99 \\
(1.51)\end{array}$ & $\begin{array}{c}\mathbf{0 . 2 3} \\
(0.11)\end{array}$ & 0.14 & $\begin{array}{c}0.96 \\
(2.22)\end{array}$ & $\begin{array}{c}-2.40 \\
(1.52)\end{array}$ & $\begin{array}{c}\mathbf{0 . 3 0} \\
(0.14)\end{array}$ & 0.07 \\
\hline Korea & $\begin{array}{c}-9.78 \\
(2.46)\end{array}$ & $\begin{array}{l}-2.51 \\
(1.63)\end{array}$ & $\begin{array}{c}\mathbf{0 . 7 2} \\
(0.13)\end{array}$ & 0.63 & $\begin{array}{l}-2.99 \\
(2.56)\end{array}$ & $\begin{array}{l}\mathbf{- 3 . 2 6} \\
(1.41)\end{array}$ & $\begin{array}{c}\mathbf{0 . 7 5} \\
(0.13)\end{array}$ & 0.42 \\
\hline Malaysia & $\begin{array}{l}-1.89 \\
(0.59)\end{array}$ & $\begin{array}{c}0.50 \\
(1.04)\end{array}$ & $\begin{array}{c}\mathbf{0 . 3 3} \\
(0.14)\end{array}$ & 0.20 & $\begin{array}{l}-1.99 \\
(1.69)\end{array}$ & $\begin{array}{c}0.35 \\
(1.20)\end{array}$ & $\begin{array}{c}\mathbf{0 . 3 5} \\
(0.15)\end{array}$ & 0.15 \\
\hline Singapore & $\begin{array}{c}-6.16 \\
(1.57)\end{array}$ & $\begin{array}{c}0.11 \\
(1.70)\end{array}$ & $\begin{array}{c}\mathbf{0 . 4 5} \\
(0.15)\end{array}$ & 0.44 & $\begin{array}{c}-3.73 \\
(1.58)\end{array}$ & $\begin{array}{c}1.16 \\
(1.57)\end{array}$ & $\begin{array}{c}\mathbf{0 . 3 8} \\
(0.13)\end{array}$ & 0.17 \\
\hline Taiwan & $\frac{-4.46}{(2.52)}$ & $\begin{array}{l}-2.29 \\
(1.66)\end{array}$ & $\begin{array}{c}\mathbf{0 . 3 7} \\
(0.13)\end{array}$ & 0.22 & $\begin{array}{l}-1.05 \\
(2.49)\end{array}$ & $\begin{array}{c}-3.10 \\
(1.53)\end{array}$ & $\begin{array}{c}\mathbf{0 . 3 9} \\
(0.14)\end{array}$ & 0.09 \\
\hline Thailand & $\frac{-4.75}{(2.59)}$ & $\begin{array}{l}-3.80 \\
(2.29)\end{array}$ & $\begin{array}{c}\mathbf{0 . 4 8} \\
(0.18)\end{array}$ & 0.30 & $\begin{array}{l}-0.05 \\
(2.17)\end{array}$ & $\begin{array}{l}-1.64 \\
(1.72)\end{array}$ & $\begin{array}{c}\mathbf{0 . 3 3} \\
(0.13)\end{array}$ & 0.05 \\
\hline
\end{tabular}




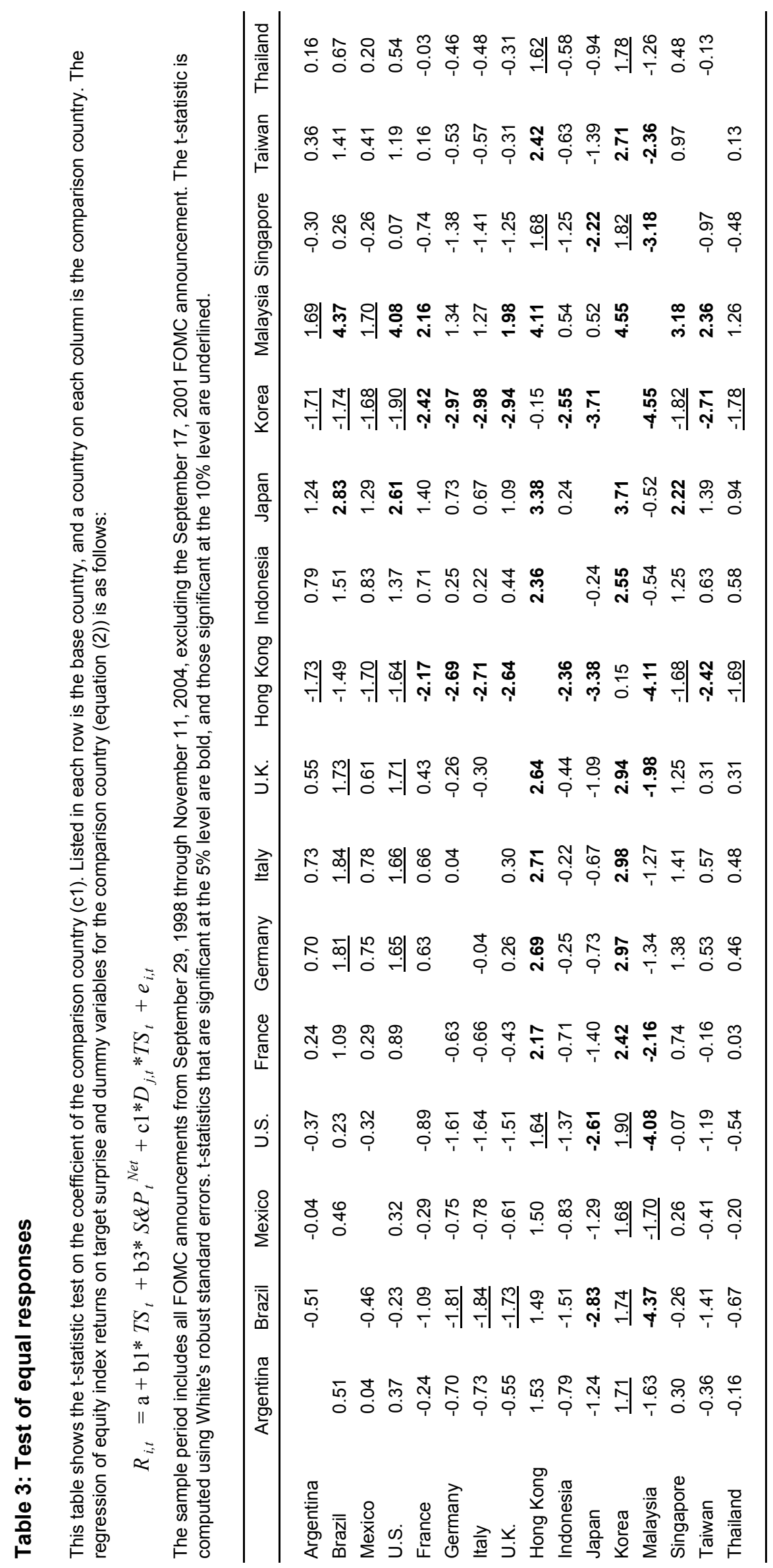




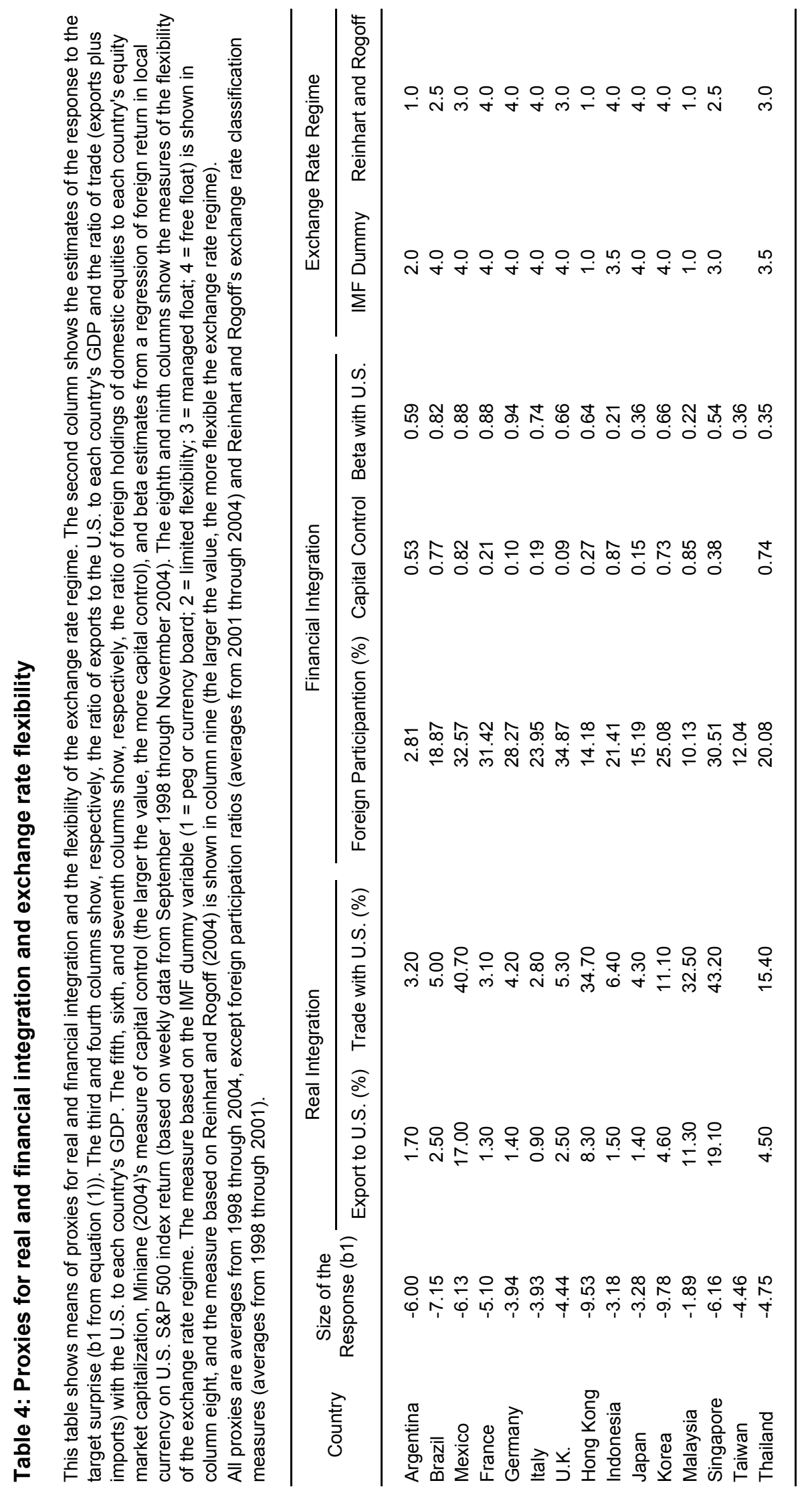




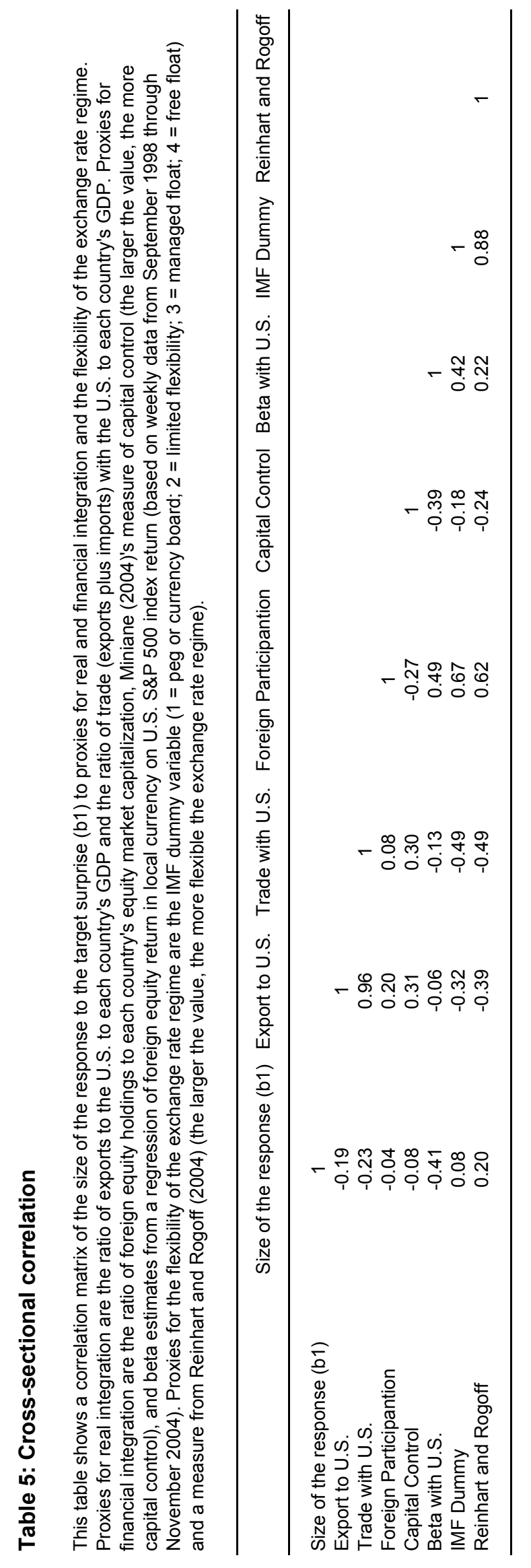




\section{Table 6: Cross-sectional regressions}

This table shows estimates from cross-sectional regressions. The regressions estimated are of the form:

Size of the response $(b 1)=\mathrm{g} 0+\mathrm{gi}^{*} X_{\mathrm{i}}$

where b1 is the estimate of the response of the equity index to the target surprise and the $X s$ are proxies for real and financial integration and for the flexibility of the exchange rate regime.

Standard errors are in parentheses. Coefficients significant at the 5\% level are in bold.

\begin{tabular}{lcc}
\hline & $(1)$ & $(2)$ \\
\hline Intercept & -3.32 & -3.86 \\
& $(2.58)$ & $(2.39)$ \\
Export to U.S. & & -0.04 \\
& & $(0.11)$ \\
Trade to U.S. & -0.03 & \\
& $(0.05)$ & \\
Beta with U.S. & -4.57 & -4.49 \\
& $(2.19)$ & $(2.12)$ \\
Reinhart and Rogoff & 0.40 & 0.49 \\
& $(0.60)$ & $(0.58)$ \\
Number of observations & 14 & 14 \\
Adj. R-sq & 0.07 & 0.05 \\
\hline
\end{tabular}




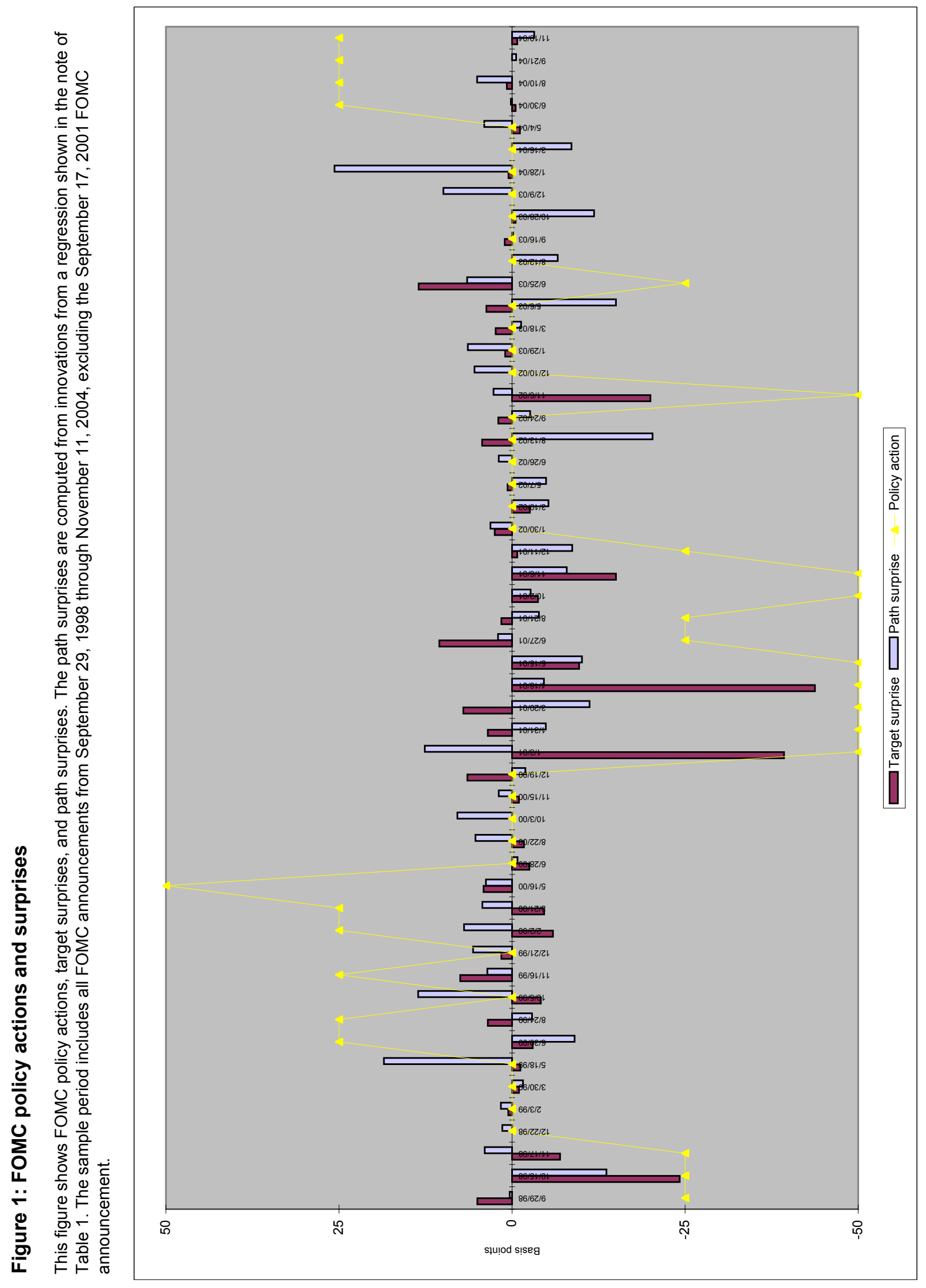




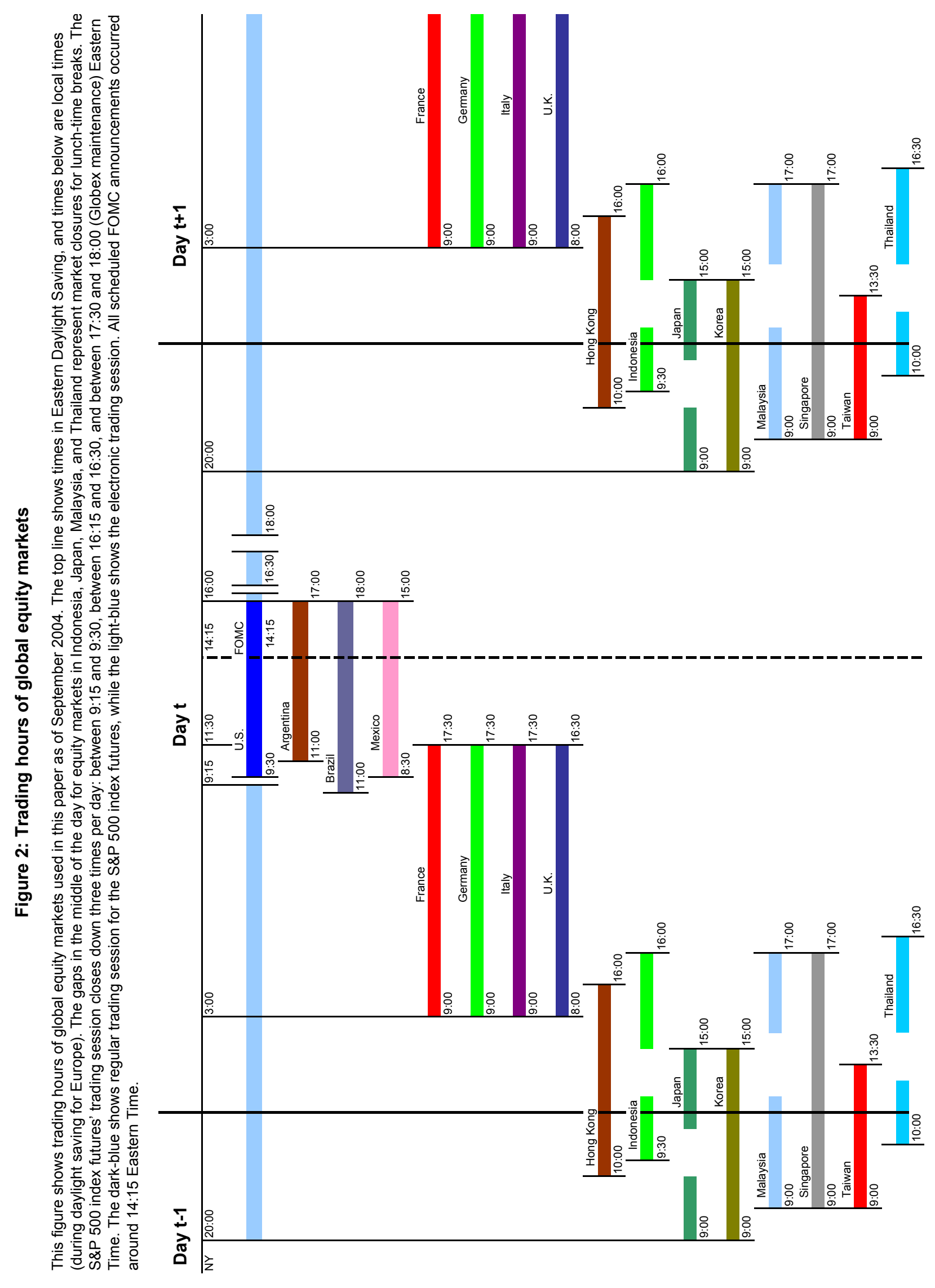


Figure 3: Volatility on FOMC and non-FOMC days

This figure shows return volatility on FOMC and non-FOMC days. The sample period includes all FOMC announcements from September 29, 1998 through November 11, 2004, excluding the September 17, 2001 FOMC announcement.
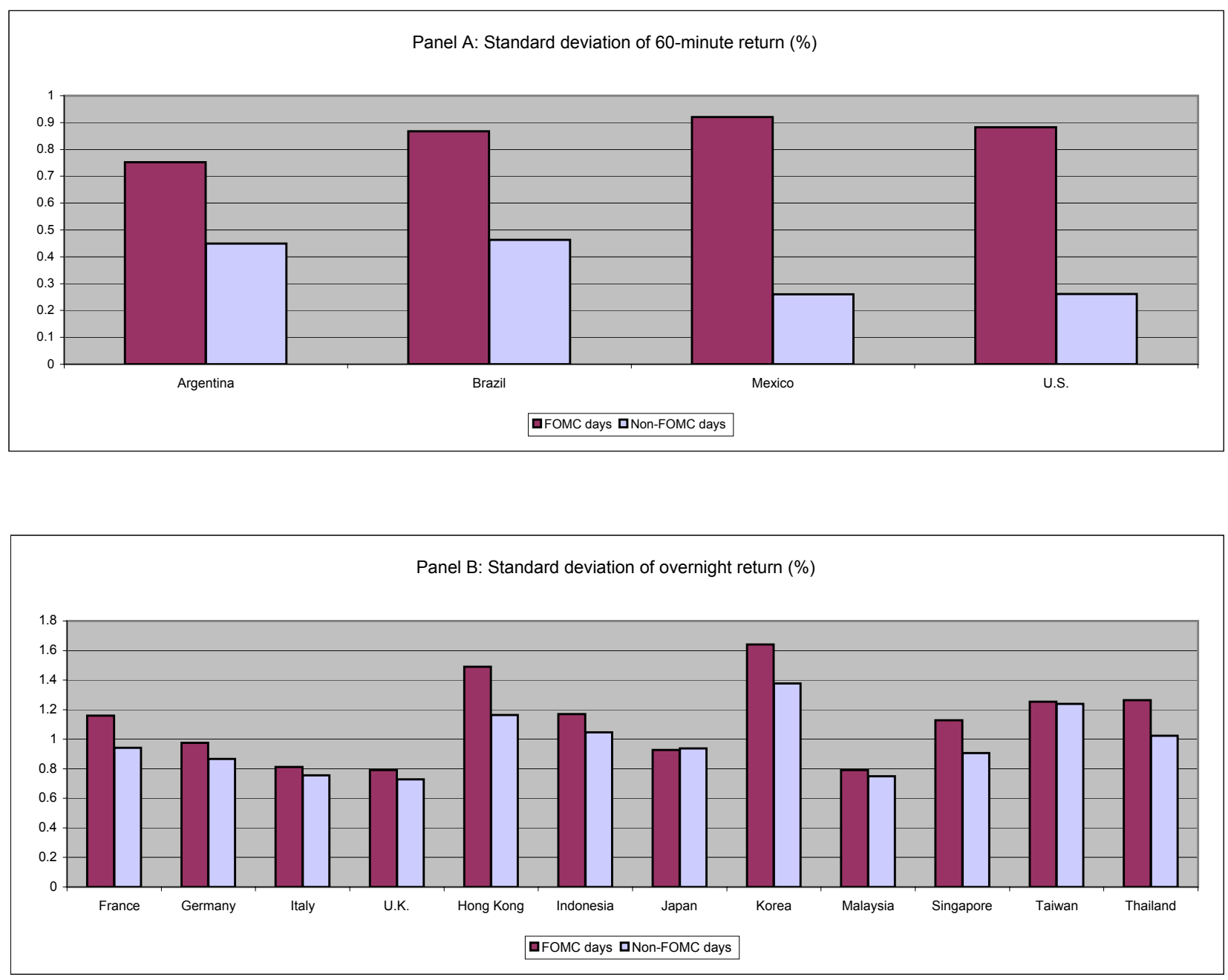